\title{
The Giants of Doubt: A Comparison between Epistemological Aspects of Descartes and Pascal
}

\author{
Cody Franchetti \\ Graduate School of Arts and Sciences, Columbia University, New York, USA \\ Email: codyfranchetti@gmail.com \\ Received May $8^{\text {th }}$, 2012; revised June $10^{\text {th }}$, 2012; accepted June 24 $4^{\text {th }}, 2012$
}

\begin{abstract}
The essay is a comparative look at Descartes' and Pascal's epistemology. For so vast a topic, I shall confine myself to comparing three crucial epistemological topics, through which I hope to evince Descartes' and Pascal's differences and points of contact. Firstly, I will concentrate on the philosophers' engagement with skepticism, which, for each, had different functions and motivations. Secondly, the thinkers' relation to Reason shall be examined, since it is the fulcrum of their thought-and the main aspect that separates them. Lastly, I will examine each philosopher's theist epistemology; this section, of course, will focus on how and by what means Descartes and Pascal set out to prove God's existence. The latter aspect shall take us back to each philosopher's relationship to Doubt: the title, "The Giants of Doubt", in fact, implies a fundamental link between Descartes and Pascal through Doubt. In addition, and most importantly, the contrast between the two thinkers' epistemology inaugurates a decisive scission in modern thought of enormous repercussion: Descartes' sturdy rationalism initiated the great branch of modern scientific enquiry, while Pascal's appeal to the power of intuition and feelings would eventually be the precursor of the reaction to the enlightenment that invested Europe by the second half of the eighteenth century. This departure of thought, which in my view may be traced back to them, has not been the common conceit of the history of philosophy: the reaction to the enlightenment has customarily been regarded as stemming from its internal contradictions or at best from its more radical doctrines. The essay shall show that these strands of thought were both parallel and born out of the antithetical epistemologies of Descartes and Pascal.
\end{abstract}

Keywords: Epistemology; Descartes; Meditations; Discourse On Method; “The Method of Doubt”; “Truth Rule”; Pascal, Pensées; Skepticism; Reason; Doubt; Theism; Modern Thought; Modern Man

\section{Introduction}

It is the task of this essay to examine a few aspects of the thought of René Descartes and Blaise Pascal and to compare their differences and points of contact. Descartes and Pascalthe two greatest European minds of the first half of the seventeenth century-were both French and roughly contemporary, yet had very little contact ${ }^{1}$, despite having many common interlocutors. Their lack of intercourse is a suggestive detail that has not been duly noted, since both thinkers also had a shared point of departure, though Descartes' main preoccupation was to shatter Scholastic philosophy, and Pascal's to gleefully ridicule Jesuit hypocrisy. That common point of departure was Montaigne-his skepticism and his language. Montaigne was a looming figure for the succeeding generation in France ${ }^{2}$ both philosophically and linguistically. After Montaigne, who was like an eye in the storm during the fractious times of the Wars of Religion which ravaged France in the second half of the sixteenth century, the French language had to be purified from spurious influences, disparate dialects, and various abuses that it picked up during those fraught times. The expurgation that the language underwent under able linguists-but second-rate poets - such as Malherbe, Racan, Maynard created a unique

\footnotetext{
${ }^{1}$ They met only once in 1647 to discuss Pascal's experiments on vacuum measurements.

${ }^{2}$ And in England too: Bacon's Essays are clearly modeled after Montaigne's Essais.
}

tool, that "machine à penser"3, the language that powered the great cogitations from Descartes to Voltaire.

Comparing the two thinkers is a thorny endeavor: Descartes was a systematic philosopher who produced a serried metaphysical structure, while Pascal was never as systematic a thinker; he left disparate works out of which his readers must infer his philosophy; yet, glimmering through his immortal aphorisms, which are but the torso of his unfinished apology for Christianity - the Pensées - it is indeed possible to ferret a theory of knowledge of his own, and it is thus possible to compare Pascal with Descartes. Because of the unmethodical nature of Pascal's philosophy, he has remained for the most part a literary and moral figure-as a thinker, unruly and enigmatic. So his influence on "mainstream" Western philosophy is somewhat peripheral, though by no means of less thrust. As to Descartes, he inaugurated modern thought and his influence in philosophy is incalculable. So the significance of both men's thought, and especially their fascinating points of departure, is such that a comparative look is of serious import even from a strictly philosophical perspective, and, I think that by engaging in a comparative look at Descartes and Pascal we may be able to trace as far back as them the great scission in modern thought-that cardinal departure between what eventually was

\footnotetext{
3“(French) particularly delights in perspicuity, and in expressing things as much as possible, in the most natural and least intricate order; though at the same time it yields to none in elegance and beauty”. Arnauld, 1753: p. 154.
} 


\section{FRANCHETTI}

to become the enlightenment, an arrant confidence in reason, and its reaction, Romanticism, a yearn toward infinitude driven by the senses' supremacy.

\section{Skepticism}

Montaigne's skepticism is an ideal entry-point for comparing the thought of Descartes and Pascal, since it was a common influence with which both thinkers deeply engaged. Descartes engaged with skepticism for epistemological motivations: skeptical arguments are not falsifiers, but underminers; they do not oppose a belief, but merely cast a belief into doubt by undermining the principle behind it, by calling into question the processes by which the belief is formed. Now in order to pave the way for his own, new thought-order Descartes had first to undermine the dominating Aristotelian philosophy, which the Scholastic tradition had merely Christianized. And so, skepticism is a useful tool for Descartes, because it casts beliefs into doubt. In Meditation One Descartes speaks of the meditator's assumed beliefs and hurls skeptical arguments at her in order to undo her thinking - most flagrantly, the old confidence in the senses. Descartes structures his first Meditation with various arguments that may induce the meditator to err: "The Madness Argument”, "The Dream Argument”, "The Mistakes of Others”, and "Chance"; these skeptical arguments are crucial for Descartes' program of eradicating two millennia of credence in the senses and planting "la raison" as the root for truth. Skepticism is therefore an effective epistemic instrument in Cartesian thought, because it permits doubt; and doubt is what Descartes shall use to demolish the old philosophical structures and erect a new, solid edifice, which can only be laid on a solid bedrock: "I kept uprooting from my mind any errors that might previously have slipped into it. In doing this I was not copying the skeptics, who doubt only for the sake of doubting and pretend to be always undecided; on the contrary, my whole aim was to reach certainty - to cast aside the loose earth and sand so as to come upon rock or clay"4. Despite his engagement with skepticism, this quote shows Descartes' wish to differentiate himself from the skeptics whose doubt is an end in itself; in fact, Descartes integrates doubt in his larger program of reformingre-erecting, in effect-the structure of knowledge for which doubt is but a step. But doubt is also the very cement with which he shall construct his new edifice-his metaphysical system: "Anything which admits of the slightest doubt I will set aside just as if I had found it to be wholly false" ${ }^{\text {". Notwith- }}$ standing all sorts of later criticisms to his thought, especially by the English empiricists, Descartes' doubt heralds the age of the "Method of Doubt"-a new age which shall be the basis for scientific enquiry until the present day.

There is another use that Descartes has for skepticism. Later in the Meditations, when Descartes shall have established the "Truth Rule", which holds that all "clear and distinct perceptions" are guaranteed to be true, he will find use for the skeptical argument one more time: now that the meditator is armed with the Truth Rule, a reliable source of truth, and is accord-

$\overline{{ }^{4} \text { CSM I 125, AT VI 29, All the quotations from Descartes in English follow }}$ the 3-volume translation by John Cottingham, Robert Stoohoff, and Dugald Murdoch (see References) and shall be cited henceforth as CSM followed by the corresponding volume (in Roman numeral) and page number; as well as the Adam \&Tannery edition abbreviated as AT, its corresponding volume, and page number.

${ }^{5}$ CSM II 16, AT VII 24 ingly thinking correctly, she shall be immune to the skeptical challenge and shall not succumb to doubt. Unlike in Meditation One, when the callow meditator still attached to Scholasticism was prey to Pyrrhonism, the knowledge attained in Meditation Four, which is founded on adamantine reason shall be beyond contestation. This application of skepticism is primarily a means for Descartes to sanction the solidity of his theory.

Pascal's engagement with skepticism, on the other hand, is quite different. To him, skeptical doubt is useful inasmuch as it shoulders man-counter intuitively - to the best possible orientation toward the religious experience:

"The main strengths of the skeptics (...) are that we have absolutely no certainty in the truth of these principles, aside from faith and revelation, except for the fact that we feel them naturally within ourselves. But this natural sentiment is not a convincing proof of their truth, since there is no certitude outside of faith that man was created by a good God or an evil demon or by pure chance it is doubtful that these principles, depending on our origin, are true, false, or uncertain. (...) Let us therefore concede to the skeptics that which they have much bawled: that the truth is not within our reach, nor in our game-bag; that it does not reside in this world; that it has affinity with the heavens; that it lives in God's bosom; and that we cannot know it if not to the degree that God fancies to reveal it to us"

Contrary to Descartes, doubt is not overcome in any way whatsoever; no rational principle can resist the skeptical challenge according to Pascal: the only real certainty is that of faith $^{7}$.

Pascal also sees the Pyrrhonist refrain from laying claims of truth as advantageous for religious revelation:

"Pyrrhonism is true. Because in the end men before Jesus Christ did not know their own condition or whether they were great or small. And those who have affirmed one thing or another did not know a thing about it and tired to guess without motive and haphazardly. And still they always erred by excluding either one or the other. Quod ergo ignorantes quaeritis, religio annuntiat vobis". (Thus by ignoring it, religion announces to you that which you seek). (The Latin quote is a non-literal citation from Acts: 17,23$)^{8}$.

There is clearly a fundamental difference in the way the two

${ }^{6}$ Pascal II, 1998: pp. 579-580 (Pensée 122) (Les principales forces des pyrrhoniens (...) sont que nous n'avons aucune certitude de la vérité de ces principles, hors la foi et la révélation, sinon en que nous les sentons naturellement en nous. Or ce sentiment naturel n'est pas une prevue convaincante de leur vérité, puisque, n’y ayany point de certitude hors la foi si l'homme est créé par un Dieu bon, par un demon méchant ou à l'aventure il est en doute si ces principes nous sont donnés veritables, ou faux, ou incertains selon notre origine. (...) Qu'on accorde donc aux pyrrhoniens ce qu'ils ont tant crié, que la vérité n’est pas de notre portée ni de notre gibier, qu'elle ne demeure pas en terre, quelle est domestique du ciel, qu'elle loge dans le sein de Dieu, et que l'on ne la peut connaître qu'à mesure qu'il lui plait de révéler).

${ }^{7}$ An alternative reading of Pascal, which may be more encompassing of his thought, as we read on, is that faith is not the only grounds for certainty; rather, we should abandon the quest for certainty altogether, and with it our trust in reason, acquiescing instead in the devotions of faith: what faith provides in not the rational security of a purified mind, but a comfort and fulfillment that is felt in the heart. (See below, on page 12: Penseé 101).

${ }^{8}$ Pascal II, 1998: p. 785 (Pensée 585) (Le pyrrhonisme est le vrai. Car après tout les homes avant Jésus-Christ ne savaient où ils en étaient, ni s'ils étaient grands ou perits. Et ceux qui ont dit l'un ou l'autre n'en savaient rien et devinaient sans raison et par hazard. Et même ils erraient toujours en excluant l'un ou l'autre. Quod ergo ignorantes quaeritis, religio annuntiat vobis). 
thinkers relate with skepticism: while Descartes uses it to establish his philosophical system and the dominion of reason, Pascal sees in the skeptical withholding of truth-claims an unintentional, ironic course to opening man to being receptive to proper religious experience, and, opposed to Descartes, if anything, skepticism is a substantiation of reason's fragility ("there is no truth outside faith", etc.). This very different stance toward reason leads us to the next aspect, which distances Descartes and Pascal crucially.

\section{Reason}

It is fascinating to behold two great mathematical mindsamong the greatest of all time ${ }^{9}$ - exhibiting antipodal positions toward reason. Already the Discourse on Method evinces Descartes' view that man, in his entirety, may be encompassed in thinking, “(...) I knew I was a substance whose whole essence or nature is simply to think, and which does not require any place, or depend on any material thing in order to exist" ${ }^{, 10}$. It is this abstraction of the mind from man that Pascal simply could not accept. Sainte-Beuve has synthesized this departure superbly:

"Descartes places himself in "methodic" doubt; he relinquishes any knowledge, habitude, and belief with an abstraction; he reduces his thought to its own self and yearns to extract from it - and from it only-every thing that this unadulterated thought is able to give him.

Thus, the whole of Pascal's enterprise and method is like a protest against this essentially speculative and independent rationalism. Pascal could not forgive that Descartes established reason as sovereign, in isolation and with an abstraction that were impossible according to Pascal" "11.

Sainte-Beuve's reading of Descartes' "methodic doubt" is quite correct. Descartes wished to give the power and competence to "isolated" thought in "its own self" (compare with Pascal's Pensées n. 512 on p. 9) to reconstruct nothing short of the world through deduction once unimpeachable truths have been established and are indubitable. But the idea that a "single system of knowledge embracing all provinces and answering all questions, could be established by unbreakable chains of logical argument from universally valid axioms"12 was refuted by the empiricists - especially Hume-who demonstrated that "no logical links existed between truths of fact and such a priori truths as those of logic or mathematics"13. Pascal's reaction to Descartes' overconfidence in the mind was quickest to arrive: starting with his De l'Esprit Géométrique, which was written in 1657 , three years after his religious conversion, we can trace the progressive refutation of science's-and therefore rea-

\footnotetext{
${ }^{9}$ If it is unnecessary to overstate the importance of the Cartesian plane, which is only one of Descartes's countless contributions to mathematics, it is equally impossible to overstate Pascal's prodigious scientific mind: at twelve years old, without the aid of any mathematical concepts or books or tutoring - his father, a celebrated magistrate, had ridden the family library of all math books to ensure that his son be a magistrate like him-had rediscovered, on his own, Euclid's first thirty-two geometric propositions; at sixteen, he wrote a treatise on conical sections, which stupefied Descartes who refused to believe that a child had redacted such work; at twenty, he invented the first calculating machine and soon after, again by himself and without any knowledge of Torricelli's work ten years earlier, Pascal conducted identical experiments on vacuum measurements.

${ }^{10}$ CSM I 127, AT VI 33.

${ }^{11}$ Sainte-Beuve I, 2004: p. 1049.

${ }^{12}$ Berlin, 1979: p. 2.

${ }^{13}$ Berlin, 1979: p. 3.
}

son's-superior claim for universal knowledge, which meaningfully proceeds specifically by means of skeptical arguments: "But since nature itself provides for everything that this science can't, then its sense of order, which is claimed to be found in the truth, cannot achieve a perfection superior to that of humans, although it does indeed achieve the perfection within humans' reach"14. As he writes about the limits of science, under the treatise's sub-heading, "Pourquoi la géométrie ne peut pas définir certaines choses” (Why geometry cannot define certain things), Pascal casts the limit of mathematics as that of a discipline of man's invention, which is thus incapable of defining or even declaring anything about what is outside its pertinence, even despite the fact that mathematics is an instrument of undisputed perfection for its province. This curiously prefigures GiambattistaVico's argument a generation later: "Vico maintained that the Cartesians were profoundly mistaken about the role of mathematics as the science of sciences, that mathematics was certain only because it was a human invention. It did not, as they supposed, correspond to an objective structure of reality; it was a method and not a body of truths; with its help we could plot regularities - the occurrence of phenomena in the external world-but not why they occurred as they did, or to what end"

Pascal's charge against reason is directed exactly to those who use it as a lantern for seeking everything - even that which according to Pascal is outside the realm of reason-and it is toward such arrant faith in reason that his scathing vein, which he used as a humorist in his Provinciales, but which here are a solemn indictment:

"I do not speak here of divine truths, which I shall take care not to comprise under the art of persuasion, because they are infinitely superior to nature: God alone can place them in the soul and in such a way as it pleases him. I know that he has desired that they should enter from the heart into the mind, and not from the mind into the heart, to humiliate that proud power of reasoning that pretends to have the right to be the judge of the things that the will chooses; and to cure this infirm will which is wholly corrupted by its filthy attachments"16.

That knowledge enters through the heart to the mind rather than conversely shall be a point on which Pascal shall insist increasingly, especially in his Pensées concerning God and man's way of apprehending him (we shall look at this fundamental opposition with Descartes in a moment).

Pascal's arraignment against reason is intensified in the Pensées. There are numerous remarks throughout directed against reason-reason upheld as the sole source of knowledge. From declarations such as "those who would only want to follow reason, according to the judgment of the majority of men, would be completely crazy"17. to pronouncements like "write

\footnotetext{
${ }^{14}$ Pascal II, 1998: p. 161 (Mais comme la nature fournit tout ce que cette science ne donnes pas, son ordre à la vérité ne donne pas une perfection plus qu'humaine, mais ils a toute celle où les homes peuvent arriver). ${ }^{15}$ Berlin 1979: p. 4.

${ }^{16}$ Pascal II, 1998: p. 171 (Je ne parle pas ici des vérités divines que je n'aurais garde de faire tomber sous l'art de persuader, car elles sont infiniment au-dessus de la nature. Dieu seul peut mettre dans l'âme, et par la manière qu'il lui plait. Je sais qu'il; a voulu qu'elles entrent du Coeur dans l'esprit, et non pas de l'esprit dans le Coeur, pour humilier cette superbe puissance du raisonnement, qui pretend devoir être juge des choses que la volonté choisit, et pour guérir cette volonté infirme, qui s'est toute corrompue par ses sales attachements).

${ }^{17}$ Pascal II, 1998: p. 553 (Pensée 41) (Qui voudrait ne suivre que la raison sarait fou prouve au jugement de la plus grande partie des homes du monde).
} 
against those who entertain too deeply the study of the sciences. Descartes"18. The inference against reason is obvious. But none exemplifies Pascal's dissent from reason's epistemic failure more than his Pensées n. 512. "The corruption of reason manifests itself in many different and extravagant ways. It took the truth to appear so that man stop living enclosed within himself" ${ }^{\prime 19}$. The danger, and hubris of reason is such, according to Pascal, that if man were to follow reason exclusively, he would be closed to the fundamental experience of living in the world, the God-ordained totality of the world, which is essential to man's cognizance of himself and the fullness of his existence.

Henceforth, a scission in thought occurred: on the one hand rationalism and its predominance, the "scientific understanding which Descartes himself so successfully inaugurated"20 dominated thought for a century through the enlightenment as the prevailing, orthodox perspective; on the other, the persuasion in the priority of intuitiveness and feeling flowed quietly yet inexorably everywhere in Europe-Pietism being an early example of the subterraneous revolt against reason. When the latter stance surfaced irresistibly, most notably in France with a Rousseau and in Germany with a Hamann, harbingers of Romanticism, the two positions remained in open conflict constantly, without secrecy, battling in almost every field of human action to this day. And yet, I think we can trace the beginning of this perpetual, elementary struggle with Descartes' pronouncement of the supremacy of reason and Pascal's challenge to it.

\section{God}

According to Descartes, the perception of God is the exclusive domain of the mind through the aid of reason: "Whatever we can know of God in this life, short of a miracle, is the result of reasoning and discursive inquiry,21.

We shall see that not only this position is antithetical to Pascal's, but it is also heretical, according to the Roman Catholic doctrine, which, despite recognizing Augustine's assertion that the illumination of reason is indeed furnished by God himself, centers the good Christian's enterprise around faith. Descartes' position on faith is ambiguous; in principle, according to him faith is important but must be aided by reason, especially concerning non-believers. "(...) since faith is the gift of God, he who gives us the gift to believe other things can also give us grace to believe that he exists. But this argument cannot be put to unbelievers because they would judge it to be circular. (...) the existence of God is capable of proof by natural reason $(\ldots)^{, 22}$. It is likely that Descartes, who wrote this in the Meditations' dedicatory letter to the Sorbonne took a diplomatic stance towards faith-for which I suspect he had little regard-because he knew that his audience might include very strict theologians that could find an unmitigated partiality against pure reason objectionable.

Thus Descartes' proof for God's existence is entirely lodged in the mind. In Meditation Three, Descartes presents a proof for God which begins with the "I am, I exist" premise and through a fairly long chain of reasoning, ends with a deductive proof of

\footnotetext{
${ }^{18}$ Pascal II, 1998: (Pensée 476) (Écrire contre ceux qui approfondissent trop les sciences. Descartes).

${ }^{19}$ Pascal II, 1998: (Pensée 512) (La corruption de la raison paraît par tant de différentes et extravagantes moeurs. Il a fallu que la vérité soit venue, afin que l'homme ne véquît plus en soi-même).

${ }^{20}$ Cottingham, 1995: p. 191.

${ }^{21}$ CSM III 331, AT V 137.

${ }^{22}$ CSM II 3, AT VII 2.
}

God that is essentially innatist ${ }^{23}$. By Meditation Five, however, the meditator's empowered mind has no need for the comfort provided by the deductive process; and so, Descartes' argument for God's existence is achieved in a quick, bold stroke:

"Certainly, the idea of God, or a supremely perfect being, is one which I find within me just as surely as the idea of any shape or number. And my understanding that it belongs to his nature that he always exists is no less clear and distinct than is the case when I prove of any shape or number that some property belongs to its nature, 24 .

This time, the proof for God's existence is not born out of deduction, rather, it is reached through modal intuition, that is, seeing an eternal truth directly through the light of reason.

Descartes' outlook could not be further from Pascal's view on the way man perceives and understands God, as the famous Pensées 101 unequivocally states: "It is the heart that senses God and not reason" 25 . And further, "That is what faith is: the heart sensitive to God"26. If we compare this with Descartes' statement from his Rules for the Direction of the Mind that "faith has a basis in our intellect"27 the antithesis between Descartes and Pascal is complete. "It is not through the risky and arduous path of metaphysical certainty that Pascal thought man should experience God, rather, he ought to do so in terms of the common morality: Pascal addresses man through his own, everyday reality"28. Sainte-Beuve once again synthesizes admirably the difference between Descartes' and Pascal's advance toward God as well as each philosopher's view on how man should endeavor himself in the discovery of God; and there is no need for further evidence to be given to discern the gulf separating the two thinkers on matters of reason and God as boundless.

I should like to chronicle an interesting aspect, which reveals that Pascal's dismissive opinion of Descartes ("inutile et incertain,29) was due in part to a genuine misunderstanding. SainteBeuve reports of a highly critical passage against Descartes in a letter Pascal's wrote, which as Sainte-Beuve rightly points out, was unusual since "Pascal writes very little about Descartes, but thinks constantly about him”30. Pascal wrote: "I cannot forgive to Descartes that in all his philosophy he would have liked to dispense with God, but he did not accomplish to contrive to forbear God's hand in giving ever so slight a push to set the world in motion. After that, Descartes had no use for God"31. Pascal's contention is understandable: he could not stand Descartes' placing God exclusively in the mind. But Pascal is mistaken in his estimation of the paucity of Descartes' need for God in his philosophical system, for his judgment of Descartes' epistemology is summary; Descartes stated clearly that the all-important Truth Rule only really arms theists, and, though he accepts that truth may also be perceived by atheists, the lat-

\footnotetext{
${ }^{23}(\ldots)$ the mere fact that I exist and have within me an idea of a most perfect being, that is, God, provides a very clear proof that God indeed exists. It only remains for me to examine how I received this idea from God. For I did not acquire it from the senses (...) And it was not invented by me either (...) The only remaining alternative is that it is innate in me, just as the idea of myself is innate in me. CSM II 35, AT VII 51.

${ }^{24} \mathrm{CSM}$ II 45, AT VII 65.

${ }^{25}$ Pascal II, 1998: p. 573 (Pensée 101) (C’est le coeur qui sent Dieu, et non la raison).

${ }^{26}$ Pascal II, 1998: p. 573 (Pensée 122) (Voilà ce que c’est la foi: Dieu sensible au Coeur).

${ }^{27}$ CSM I 15, AT X 370.

${ }^{28}$ Sainte-Beuve I, 2004: p. 1052.

${ }^{29}$ Pascal II, 1998: p. 566 (Pensée 77).

${ }^{30}$ Sainte-Beuve I, 2004: p. 1050.

${ }^{31}$ Sainte-Beuve I, 2004: p. 1051.
} 
ter can only ascribe the cognition of truth to chance, which is prey to all sorts of deceptions; their cognition is an inferior form of truth-apprehension, because by lying outside the Truth Rule it shall always be prey to Retrospective Doubt-until they have admitted God.

"The fact that an atheist can be clearly aware that the three angles of a triangle are equal to two right angles is something I cannot dispute. But I maintain that this awareness of his is not true knowledge, since no act of awareness that can be rendered doubtful seems fit to be called knowledge. Now since we are supposing that this individual is an atheist, he cannot be certain that he is not being deceived on matters which seem to him to be very evident (...) And although this doubt may not occur to him, it can still crop up if someone else raises the point or if he looks into the matter himself. So he will never be free of this doubt until he acknowledges that God exists"32.

Clearly then, Descartes had more use for God than Pascal thought, though we have seen that they diverge indisputably over the epistemic means by which man apprehends God as well as the course to take for the proof of God.

And yet, there are points of contact between Pascal and Descartes; the former reveals two key, corresponding epistemological aspects with Descartes. Firstly, Pascal, in defining axioms in his De l'Art de Persuader, which is an appendage to his De l'Esprit Géométrique, determined "not to demand, in axioms, any but things that are perfectly evident of themselves"33. In his definition - or as he labeled it "règle pour les axioms"-Pascal implies that these principles can only be perceived through intuition exactly like Descartes' "clear and distinct perceptions", which include mathematical axioms. The similarity is explicit. Secondly, and more importantly, Pascal gives Descartes full credit for the "Cogito":

"I would inquire of reasonable persons whether this principle: Matter is naturally wholly incapable of thought, and this other: I think, therefore I am, are in fact the same in the mind of Descartes, and in that of St. Augustine, who said the same thing twelve hundred years before. In truth, I am far from affirming that Descartes is not the real author of it, even though he may have learned it only in reading this distinguished saint; for I know how much difference there is between writing a word by chance without making a longer and more extended reflection on it, and perceiving in this word an admirable series of conclusions, which prove the distinction between material and spiritual natures, and making of it a firm and sustained principle of a complete metaphysical system, as Descartes has pretended to do. For without examining whether he has effectively succeeded in his pretension, I assume that he has done so, and it is on this supposition that I say that this expression is as different in his writings from the same saying in others who have said it by chance, as is a man full of life and strength from a corpse, ${ }^{34}$.

Pascal wrote tellingly, "as Descartes has pretended to do" (my italics); and the annotators of the Gallimard edition of his complete works justly note that "his reservation is of importance: Pascal does not adhere to Cartesianism nor does he interest himself in it”35. Nevertheless, Pascal acknowledges Descartes as the first to have sanctioned the Cogito as "a principle of a complete metaphysical system”. Understandably Pascal follows Descartes only to a point-matters of pure mathematics - but when the question of man's apprehension and understanding of God rises, he completely diverges from Descartes. This is manifested in the quotation above, since to say "I am" unavoidably puts God into the argument, and we have clearly seen how much Descartes and Pascal differ in matters concerning the epistemology of God.

\section{The Giants of Doubt}

I have entitled this essay "The Giants of Doubt” referring to Descartes and Pascal, because doubt represents a fundamental characteristic of their thought and because both philosophers have elevated doubt, each in his own way, to hitherto unthought importance. Just as their thought radically diverges, so does their relationship to doubt. And yet, counter-intuitively, this difference also unites them: both Descartes and Pascal confronted doubt and quashed its hazards. Descartes brandished doubt to destroy the old-order and establish modern thought-self-sufficient reason and rational thought dispossessed from the world. Furthermore, Descartes elevated doubt to a method - the Method of Doubtand such method became an epistemic principle that had incalculable consequences for science and logic; for example, Descartes' Method of Doubt was immediately inducted into the enormously influential Port-Royal Logique: “(...) what M. Descartes proposes in his Method may be useful for preserving us from error, when seeking the truth in human sciences, although, indeed, it applies generally to all kinds of method (...),36.

Pascal reacted against this, and, recognizing the perils of reason, of absolute certainty, felt doubt increasingly mounting in him. In his supreme aphorism, "You would not seek me, if you had not found me"37, his affrighting, fertile uncertainty releases from within us a prodigious moral force: Pascal's doubt is the result of the all-embracing grasp of the contrast between man's greatness and his wretchedness, the contradiction that is at the root of our essence: "All [our] miseries prove [our] greatness. They are the miseries of a noble soul-miseries of a dispossessed king" ${ }^{, 3}$. The answer to this anguish, to this enigma, to this incongruent nature, is in God:

\footnotetext{
${ }^{35}$ Pascal II, 1998: p. 1198.

${ }^{36}$ Arnauld, 1861: p. 315.

${ }^{37}$ Pascal II, 1998: p. 615 (Pensée 187) (Tu ne me chercherais pas, sit tu ne m’avais trouvé).

${ }^{38}$ Pascal II, 1998: p. 575 (Pensée 107) (Toutes ces misères-là mêmes prouvent sa grandeur. Ce sont misères de grand seigneur, misères d'un roi dépossedé).

${ }^{39}$ Pascal II, 1998: p. 582 (Pensée 122) (II paraît que Dieu, voulant nous render la difficulté de notre être intelligible à nous-mêmes, en a caché le noeud si haut, ou pour mieux dire si bas, que nous étions bien incapables d'y arriver. De sorte que ce n'est point par les superbes agitations de notre raison, mai par la simple soumission de la raison, que nous pouvons véritablement nous connaître).
} 


\section{FRANCHETTI}

"It seems that God, wanting to make incomprehensible to us the paradox of our own nature, has hidden its solution by placing it so high up, or better, so below, that we are unable to reach it. So it is not with the haughty gestures of our reason, but with its simple submission that we can truly know ourselves" ${ }^{\text {"39 }}$.

Blaise Pascal's Pensées are a dramatic act-the struggle of faith against doubt; René Descartes' Meditations elevate doubt to a propaedeutic act. Pascal's restless, disquiet temperament is a stormy peak of doubt and faith, an assimilation of our fractious character; Descartes' serene intransigence, born out of the first metaphysical system in two millennia and based on the certitude emerging from this inauguration, is its complementing opposite.

And they, together, represent modern man in his fullest expression.

\section{REFERENCES}

Arnauld, A. (1753). Port-royal grammar: General and rational grammar, containing the fundamentals of the art of speaking, explained in a clear and natural manner. London: J. Nourse.

Arnauld, A. et al. (1861). Port-royal logic. London: Hamilon, Adams \& Co.,

Berlin, I. (1979) Against the current: Essays in the history of ideas. New York: The Viking Press.

Descartes, R. (2008). The philosophical writings of descartes. In J. Cottingham, R. Stoothoff, \& D. Murdoch (Eds. and Trans.), (3 Volumes). Cambridge: Cambridge University Press.

Cottingham, J. (1995). Descartes. In T. Honderich, (Ed.), The Oxford companion to philosophy. Oxford: Oxford University Press.

Pascal, B. (1998) Oeuvres complètes. Paris: Gallimard.

Sainte-Beuve, C. A. (2004). Port Royal. Paris: Robert Laffont. 